\title{
The Impact of Pre-Slaughter Fasting on the Ruminal Microbial Population of Commercial Angus Steers
}

\author{
Christina Breanne Welch ${ }^{1}{ }^{\circledR}$, Jeferson M. Lourenco ${ }^{1}{ }^{\circledR}$, Darren S. Seidel ${ }^{1}$, Taylor Rae Krause ${ }^{1}$, \\ Michael J. Rothrock ${ }^{2}$, T. Dean Pringle ${ }^{1}$ and Todd R. Callaway ${ }^{1, *(D)}$ \\ 1 Department of Animal and Dairy Science, University of Georgia, Athens, GA 30602, USA; \\ Christina.Welch@uga.edu (C.B.W.); jefao@uga.edu (J.M.L.); dsseidel18@gmail.com (D.S.S.); \\ Taylor.Krause@uga.edu (T.R.K.); dpringle@uga.edu (T.D.P.) \\ 2 Egg Safety and Quality Research Unit, Richard B. Russell Research Center, Agricultural Research Service, \\ USDA, Athens, GA 30605, USA; michael.rothrock@usda.gov \\ * Correspondence: todd.callaway@uga.edu
}

Citation: Welch, C.B.; Lourenco, J.M.; Seidel, D.S.; Krause, T.R.; Rothrock, M.J.; Pringle, T.D.; Callaway, T.R. The Impact of Pre-Slaughter Fasting on the Ruminal Microbial Population of Commercial Angus Steers.

Microorganisms 2021, 9, 2625. https:// doi.org/10.3390/microorganisms 9122625

Academic Editor: Francesca Turroni

Received: 26 November 2021

Accepted: 15 December 2021

Published: 19 December 2021

Publisher's Note: MDPI stays neutral with regard to jurisdictional claims in published maps and institutional affiliations.

Copyright: (c) 2021 by the authors. Licensee MDPI, Basel, Switzerland. This article is an open access article distributed under the terms and conditions of the Creative Commons Attribution (CC BY) license (https:/ / creativecommons.org/licenses/by/ $4.0 /)$.

\begin{abstract}
Diet impacts the composition of the ruminal microbiota; however, prior to slaughter, cattle are fasted, which may change the ruminal microbial ecosystem structure and lead to dysbiosis. The objective of this study was to determine changes occurring in the rumen after pre-slaughter fasting, which can allow harmful pathogens an opportunity to establish in the rumen. Ruminal samples were collected before and after pre-slaughter fasting from seventeen commercial Angus steers. DNA extraction and 16S rRNA gene sequencing were performed to determine the ruminal microbiota, as well as volatile fatty acid (VFA) concentrations. Microbial richness (Chao 1 index), evenness, and Shannon diversity index all increased after fasting $(p \leq 0.040)$. During fasting, the two predominant families Prevotellaceae and Ruminococcaceae decreased ( $p \leq 0.029)$, whereas the remaining minor families increased $(p<0.001)$. Fasting increased Blautia and Methanosphaera $(p \leq 0.003)$, while Campylobacter and Treponema tended to increase $(p \leq 0.086)$. Butyrate concentration tended to decrease $(p=0.068)$ after fasting. The present findings support that fasting causes ruminal nutrient depletion resulting in dysbiosis, allowing opportunistic pathogens to exploit the void in the ruminal ecological niche.
\end{abstract}

Keywords: microbiome; rumen; steer; fasting; dysbiosis; slaughter; Blautia; Methanosphaera; Campylobacter; Treponema

\section{Introduction}

Diet is one of the main driving forces of the microbial composition within the rumen [1-3], and the microbes best able to utilize dietary nutrients have a competitive advantage. The ruminal bacterial population can be broadly classified into two main niches-fibrolytic and amylolytic [4]. When a ruminant is fed a diet mainly consisting of forages, fibrolytic bacteria tend to dominate the ruminal microbial ecosystem [5,6], whereas, when ruminants are fed a high concentrate diet, amylolytic bacteria are predominant [7]. During beef cattle production, the diet fed to cattle generally changes from forage- to grain-based during the finishing phase.

Throughout the production cycle, ruminal nutrient concentrations derived from the diet drive selective pressures on the microbial population; however, cattle are often fasted for 24-36 h prior to slaughter (i.e., lairage). During fasting, the ruminal microbial population depletes the rumen of available nutrients, altering or removing the selective pressures on the rumen microbial ecosystem. Removing selective pressure can lead to a destabilization of the microbial population, or a dysbiosis, that allows opportunistic pathogens a chance to increase their populations in the rumen. Fasting cattle also reduces gastrointestinal concentrations of volatile fatty acids (VFA), which inhibit ruminal populations of Salmonella and E. coli [8]; thus, fasting allows foodborne pathogenic bacteria to increase their 
populations in the rumen and feces of cattle [9-11]. Since cattle are often asymptomatic carriers of foodborne pathogenic bacteria such as Shiga-toxin-producing Escherichia coli (STEC), Salmonella, and Camplyobacter [12-14], fasting increases the channel by which these pathogens can enter the food chain during the slaughter process.

The objective of this study was to evaluate shifts that occur in the ruminal bacterial abundance as a result of pre-slaughter fasting, and to determine if fasting resulted in ruminal dysbiosis in cattle. We hypothesized that removal of nutrient- and VFA-driven selective pressure during fasting would result in dysbiosis that could allow pathogenic bacteria the opportunity to expand their populations in the gastrointestinal tract, ultimately compromising food safety.

\section{Materials and Methods}

\subsection{Animal Selection and Handling}

All steers in this study were handled according to the guidelines approved by the University of Georgia's Animal Care and Use Committee (AUP \#A2012 11-006-R1). Steers were reared on a pasture-based system for their first year at the Northwest Georgia Research and Education Center, located in Calhoun, GA ( $\left.34^{\circ} 30^{\prime \prime} \mathrm{N}, 84^{\circ} 57^{\prime \prime} \mathrm{W}\right)$. After weaning and backgrounding, a total of 63 steers were transported to a commercial feedlot located in Brasstown, NC $\left(35^{\circ} 10^{\prime \prime} \mathrm{N}, 83^{\circ} 23^{\prime \prime} \mathrm{W}\right)$. The animals were then transitioned to a feedlotfinishing ration using a step-up approach for 3 weeks. Following transition, the steers were fed a finishing diet for 110 days. The finishing diet provided $14.51 \%$ crude protein, $2.10 \mathrm{Mcal} / \mathrm{kg} \mathrm{NEm}, 1.43 \mathrm{Mcal} / \mathrm{kg} \mathrm{NEg}, 0.70 \% \mathrm{Ca}$, and $0.45 \% \mathrm{P}$.

During the feedlot-finishing period, the steers were fed using a GrowSafe System (GrowSafe Systems Ltd., Calgary, AB, Canada), which measured the individual feed intake of each steer. Intake data, along with animal performance data, allowed for calculation of the residual feed intake (RFI) for each steer. An RFI value is a measure of feed efficiency calculated by subtracting the actual feed intake from the expected feed intake, where a negative RFI value means the steer is eating less than expected for their level of production and is more desirable to producers [15-17]. The steers most divergent in terms of RFI status $(n=17)$ were utilized during this study. Of this group, 8 were considered less-efficient (high-RFI) and 9 were assigned to the more-efficient group (low-RFI). These animals were transported to the University of Georgia Meat Science Technology Center, a federally inspected meat plant located in Athens, GA ( $\left.33^{\circ} 57^{\prime \prime} \mathrm{N}, 83^{\circ} 22^{\prime \prime} \mathrm{W}\right)$. The steers were housed on site overnight with ad libitum access to water before humane slaughter the next morning.

\subsection{Rumen Content Collection and Storage}

Upon arrival at the slaughter facility, rumen fluid was individually collected from all steers following the procedures described in Lourenco et al. [18]. Briefly, this procedure utilized esophageal tubing and a perforated metal probe, which is attached to an electric vacuum pump for collection of the ruminal contents. Approximately $350 \mathrm{~mL}$ of ruminal contents was collected from each animal. Immediately after, a subsample of $45 \mathrm{~mL}$ was transferred to a sterile conical tube, and the tubes were stored in a $-20{ }^{\circ} \mathrm{C}$ freezer until further processing. The following morning (16 h after the first collection, and after $24 \mathrm{~h}$ of fasting), after slaughter and evisceration of the carcasses, rumens were identified and cut into using a flame-sterilized scalpel. Approximately $45 \mathrm{~mL}$ of rumen contents was aseptically removed from the rumen and placed into sterile conical tubes and immediately taken to a $-20^{\circ} \mathrm{C}$ freezer for long-term storage until DNA extraction and volatile fatty acid (VFA) analysis were performed approximately four months later.

\subsection{DNA Extraction and Sequencing}

Bacterial DNA extraction was performed on the ruminal samples using a hybrid protocol described by Rothrock et al. [19] utilizing mechanical and enzymatic means of extraction to optimize results. Briefly, this procedure used either $330 \mu \mathrm{L}$ of rumen fluid (prelairage) or $330 \mathrm{mg}$ of rumen contents (post-lairage) placed in $2 \mathrm{~mL}$ Lysing Matrix E tubes 
(MP Biomedicals LLC, Irvine, CA, USA). The tubes were homogenized using a FastPrep 24 Instrument (MP Biomedical LLC, Irvine, CA, USA) in order to mechanically disrupt the cells. Enzymatic extraction occurred with the use of InhibitEX Tablets (QIAGEN, Venlo, The Netherlands). DNA from each sample was eluted and purified using an automated robotic workstation (QIAcube; QIAGEN, Venlo, The Netherlands). After extraction was completed, the concentration and purity of the DNA within each sample was measured spectrophotometrically using the Synergy H4 Hybrid Multi-Mode Microplate Reader along with the Take3 Micro-Volume Plate (BioTek Instruments Inc.; Winooski, VT, USA). In order to have sequencing performed, each sample had to meet a minimum requirement of $20 \mu \mathrm{L}$ of volume present with a DNA concentration of at least $10 \mathrm{ng} / \mu \mathrm{L}$. Samples failing to meet these minimum requirements were discarded and a new DNA extraction cycle was performed.

16S rRNA gene sequencing was performed at the Georgia Genomics and Bioinformatics Core. The library was prepared using PCR replications with the forward primer: S-D-Bact0341-b-S-17 (5'-CCTACGGGNGGCWGCAG-3') and the reverse primer: S-D-Bact-0785-a-A21 (5'-GACTACHVGGGTATCTAATCC-3') [20]. An Illumina MiSeq v3 $2 \times 300$ base pairs kit (Illumina Inc., San Diego, CA, USA) was utilized for the $16 \mathrm{~S}$ rRNA gene sequencing.

At the completion of sequencing, the data were demultiplexed and converted to FASTQ files. BBMerge Paired Read Merger v37.64 was used to set and merge pair-end reads. The files were then analyzed using QIIME pipeline v1.9.1 [21]. The data files were quality filtered and merged into a single file and converted to the FASTA format. Sequences were grouped into operational taxonomic units (OTU) at 97\% similarity using the Greengenes database (gg_13_8_otus). Singletons were excluded from the analysis. The sequence depth was set at 17,542 sequences per sample for further analysis. In addition to the quality control steps implemented by Illumina, the quality of the sequence calls was performed using QIIME's standard "split_libraries_fastq.py" script. Following OTU picking, sequences were aligned using the PyNAST method, which aligns sequences to a Greengenes template that is free of chimeric sequences [22]. Cyanobacterial and mitochondrial 16S rRNA genes were excluded from the analysis.

\subsection{Volatile Fatty Acid Analysis}

Analysis of VFA was performed following the procedures previously described by Lourenco et al. [23]. For the rumen fluid samples collected when the steers arrived at the slaughter facility, the samples were thawed and vortexed for $30 \mathrm{~s}$ to produce homogenized samples. Then, $1.5 \mathrm{~mL}$ of each sample was pipetted into a centrifuge tube. For the rumen contents collected at slaughter, the tubes were thawed, and $1 \mathrm{~g}$ of rumen contents was diluted with $3 \mathrm{~mL}$ of distilled water and placed into $15 \mathrm{~mL}$ conical tubes. The conical tubes were vortexed for $30 \mathrm{~s}$ to homogenize the samples, and $1.5 \mathrm{~mL}$ of the mixture from each tube was transferred into new centrifuge tubes. The tubes were centrifuged at $10,000 \times g$ for $10 \mathrm{~min}$. For each sample, $1 \mathrm{~mL}$ of supernatant was then transferred to a new centrifuge tube and combined with $200 \mu \mathrm{L}$ of a metaphosphoric acid solution ( $25 \% w / v)$. Each sample was vortexed for $30 \mathrm{~s}$ to ensure proper mixture and then stored at $-20{ }^{\circ} \mathrm{C}$ overnight. The following morning, samples were thawed and centrifuged at $10,000 \times g$ for $10 \mathrm{~min}$. The supernatant was then placed into polypropylene tubes with ethyl acetate in a 2:1 ratio of ethyl acetate to supernatant. The samples were vortexed for $10 \mathrm{~s}$ and allowed to settle for $5 \mathrm{~min}$ to optimize separation. Next, $600 \mu \mathrm{L}$ of the top layer was transferred into screw-thread vials for analysis of the VFA concentrations. A Shimadzu GC-2010 Plus gas chromatograph (Shimadzu Corporation, Kyoto, Japan) with a flame ionization detector and a capillary column (Zebron ZB-FFAP; $30 \mathrm{~m} \times 0.32 \mathrm{~mm} \times 0.25 \mu \mathrm{m}$; Phenomenex Inx., Torrance, CA, USA) was used for VFA analysis. This equipment utilized helium as the carrier gas. Sample injection volume was $1.0 \mu \mathrm{L}$. The column temperature started at $110{ }^{\circ} \mathrm{C}$ and gradually increased to $200{ }^{\circ} \mathrm{C}$. The injector and detector temperatures were set to $250{ }^{\circ} \mathrm{C}$ and $350^{\circ} \mathrm{C}$, respectively. 


\subsection{Statistical Analysis}

Statistical analysis was performed using Minitab v.19.1. Differences in the alpha diversity indexes and bacterial relative abundances upon arrival at the slaughter facility and after slaughter were calculated using paired t-tests with the model:

$$
t=\frac{\bar{d}-\mu_{d_{0}}}{s_{\bar{d}}}
$$

where $\bar{d}$ is the sample mean difference, $\mu_{d_{0}}$ is the hypothesized population mean difference, $s_{\bar{d}}=s_{\bar{d}} / \sqrt{ } n, \mathrm{n}$ is the number of samples differences, and $s_{\bar{d}}$ is the standard deviation of the sample difference. Several bacterial taxa were found to be significantly different as a result of pre-slaughter fasting; however, selection of bacterial taxa presented was based on the ones found in the literature to potentially pose a threat to human or host health. In addition, multiple Pearson correlations were performed between bacterial abundances and VFA concentrations. Based on the magnitude and significance of the correlations $(p<0.05)$, linear regression analyses were performed between selected bacterial taxa and VFA concentrations using the method of least squares. Results were considered significant at $p \leq 0.05$ and treated as trends when $0.05<p \leq 0.10$.

\section{Results}

Pre-slaughter fasting dramatically impacted the overall alpha-diversities of the ruminal microbial ecosystem (Table 1). For the high-RFI (low efficiency) steers, there was an increase in bacterial richness (Chao $1 ; p=0.001)$, evenness $(p=0.040)$, and diversity (Shannon index; $p=0.001$ ) in the rumen samples collected at lairage compared to those at slaughter. Similarly, bacterial richness (Chao 1), evenness, and diversity (Shannon index) were higher $(p \leq 0.03$ ) in the rumen of low-RFI (high efficiency) steers at slaughter compared to lairage. Since the impact of pre-slaughter fasting displayed similar patterns in bacterial populations regardless of feed efficiency status, high- and low-RFI steers were pooled $(n=17)$ for further analyses.

Table 1. Ruminal microbial alpha-diversity of high-RFI $(n=8)$ and low-RFI $(n=9)$ steers observed at lairage and slaughter (after fasting overnight).

\begin{tabular}{ccccc}
\hline Index & \multicolumn{4}{c}{ High-RFI Steers } \\
\hline & Lairage & Slaughter & SEM & $p$-Value \\
\hline Chao 1 & 2791 & 3786 & 177 & 0.001 \\
Shannon Index & 8.18 & 8.59 & 0.072 & 0.001 \\
Evenness & 0.768 & 0.786 & 0.007 & 0.040 \\
\hline \multicolumn{5}{c}{ Low-RFI Steers } \\
\hline Chao 1 & Lairage & Slaughter & SEM & $p$-Value \\
Shannon Index & 2499 & 3051 & 204 & 0.027 \\
Evenness & 7.92 & 8.45 & 0.161 & 0.011 \\
\hline
\end{tabular}

The taxonomic profile at the phylum and family level can be found in the supplementary material (Figure S1). All the bacterial families were combined, except for the two most abundant families, Prevotellaceae and Ruminococcaceae, which comprised greater than $53 \%$ of the total relative abundance upon arrival (Figure 1). However, after fasting, the abundance of Prevotellaceae decreased from 28.18 to $21.36 \%(p=0.029)$ and Ruminococcaceae decreased from 25.69 to $17.03 \%$ ( $p=0.002$ ) for a combined $38.39 \%$ of the ruminal environment. Consequently, the bacterial abundance of the minor families (e.g., Lachnospiraceae, Order Clostridiales, S24-7, and Veillonellaceae) was increased from 46.13 to $61.61 \%(p<0.001)$ during the overnight pre-slaughter fasting period. 


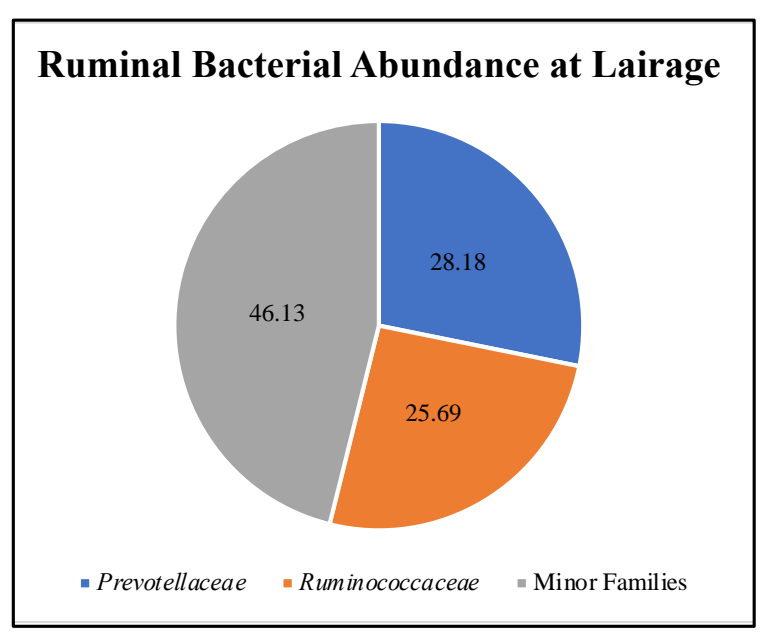

(a)

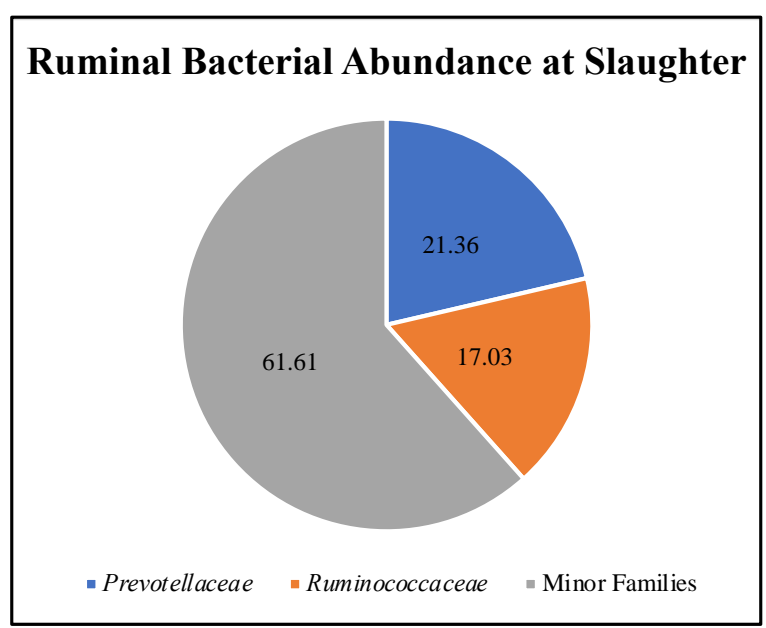

(b)

Figure 1. Relative bacterial abundance in the rumen of Angus steers $(n=17)$ observed at lairage (a) and, after fasting overnight, at slaughter (b) (after fasting overnight). Family abundance differed after fasting $(p \leq 0.03)$.

At the genus level, two well-known foodborne pathogens, STEC and Salmonella, were not detected in the rumen of steers before or after pre-slaughter fasting. However, multiple bacterial genera that contain harmful or undesirable species for ruminant animals were detected in a greater abundance after fasting. Blautia $(p=0.003$; Figure 2a) and Methanosphaera ( $p<0.001$; Figure 2b) significantly increased in relative abundance in the rumen as a result of fasting. Campylobacter tended to increase $(p=0.075)$ in the rumen of steers after fasting (Figure 2c). Additionally, the genus Treponema tended to increase $(p=0.086)$ in abundance after pre-slaughter fasting (Figure 2d).

\begin{tabular}{|c|c|c|c|}
\hline $\mathbf{a}$ & Blautia Abundance & $\mathbf{b}$ & Methanospaera Abundance \\
\hline 0.25 & $P=0.003$ & 0.08 & $P<0.001$ \\
\hline 0.2 & S & 0.06 & \\
\hline 0.15 & & & \\
\hline 0.1 & I & 0.07 & \\
\hline & & 0.02 & 1 \\
\hline & Blautia & & Methanosphaera \\
\hline & $\|$ Lairage $\|$ Slaughter & & - Lairage $\quad$ Slaughter \\
\hline c & Campylobacter Abundance & d & Treponema Abundance \\
\hline 0.01 & & 3 & \\
\hline 0.008 & $P=0.075$ & 2.5 & $P=0.086$ \\
\hline 0.006 & & 2 & \\
\hline 0.004 & & $\begin{array}{r}1.5 \\
1\end{array}$ & 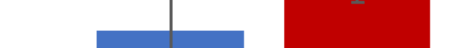 \\
\hline 0.002 & & 0.5 & \\
\hline 0 & Campylobacter & 0 & Treponema \\
\hline & - Lairage $\|$ Slaughter & & - Lairage $\|$ Slaughter \\
\hline
\end{tabular}

Figure 2. Relative bacterial abundances of: (a) Blautia, (b) Methanosphaera, (c) Campylobacter, and (d) Treponema in the rumen of Angus steers $(n=17)$ before (lairage) and after (slaughter) $16 \mathrm{~h}$ pre-slaughter fasting occurred. Error bars indicate the standard error of the mean. $p$-values indicate the difference between bacterial abundance from lairage to slaughter. 
VFA concentrations before and after pre-slaughter fasting are demonstrated in Table 2. Fasting did not show any significant impact on ruminal VFA concentrations $(p>0.05)$. Butyrate concentrations, however, exhibited a decreasing trend in concentration after fasting from lairage to slaughter $(p=0.07)$.

Table 2. Ruminal volatile fatty acid concentration $(\mathrm{mM})$ of commercial Angus steers $(n=17)$ at lairage and slaughter (after fasting overnight for $16 \mathrm{~h}$ ).

\begin{tabular}{ccccc}
\hline Volatile Fatty Acid & Lairage & Slaughter & SEM & $p$-Value \\
\hline Acetate & 62.50 & 62.73 & 6.740 & 0.97 \\
Propionate & 26.13 & 22.50 & 4.520 & 0.43 \\
Isobutyrate & 1.29 & 1.27 & 0.081 & 0.88 \\
Butyrate & 14.06 & 10.71 & 1.710 & 0.07 \\
Isovalerate & 3.27 & 3.70 & 0.397 & 0.30 \\
Valerate & 1.71 & 1.76 & 0.467 & 0.91 \\
Total volatile fatty acid & 109.21 & 103.56 & 13.100 & 0.67 \\
Acetate: Propionate & 2.63 & 3.18 & 0.332 & 0.12 \\
\hline
\end{tabular}

The relative abundance of Treponema was positively correlated with ruminal butyrate concentrations. As butyrate concentrations increased before pre-slaughter fasting, Treponema relative abundance also increased $\left(R^{2}=41.5 \%\right.$; Figure 3a). Similarly, butyrate concentrations in the rumen were related to the relative abundance of Treponema in the rumen of steers after fasting $\left(R^{2}=28.6 \%\right.$; Figure $\left.3 b\right)$.

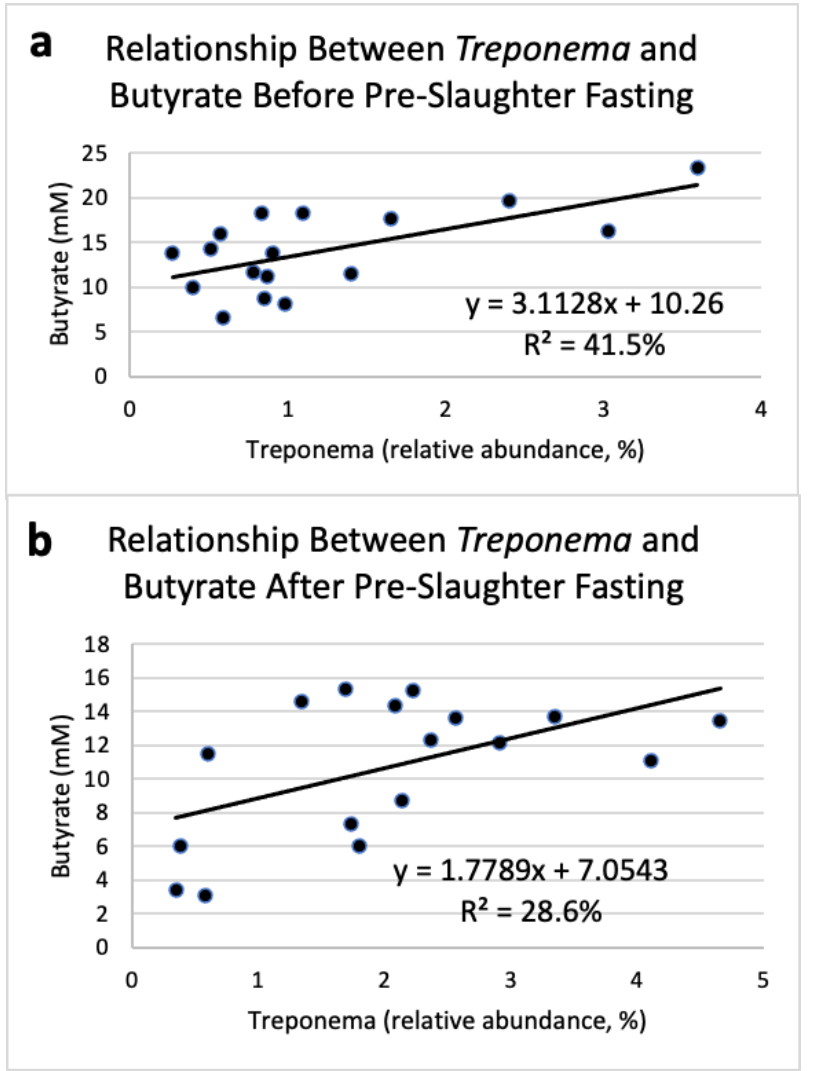

Figure 3. Linear regression expressing the relationship between Treponema relative abundance and butyrate concentration prior to pre-slaughter fasting (a) and after $16 \mathrm{~h}$ of pre-slaughter fasting (b) in the rumen of Angus steers ( $n=17)$. 


\section{Discussion}

Ruminal microbial populations of steers were significantly influenced by pre-slaughter fasting with bacterial richness, evenness, and diversity all increasing as a result of fasting. These results highlight the immense effect fasting has upon the rumen bacterial populations. Normally, with a regular flow of nutrients into the rumen, ecological niches are filled by the bacteria best able to utilize nutrients provided by the diet $[3,24,25]$. In the present study, however, fasting removed dietary selective pressure in the rumen and resulted in the number of bacterial species (richness) being increased, and the distribution of these species being more equal (evenness), ultimately increasing microbial diversity in the rumen post-fasting.

Blautia is a carbohydrate-fermenting bacterium normally found throughout the GIT of young calves; however, its relative abundance decreases as calves age [26]. Additionally, Blautia populations increased in abundance in the rumen of cattle fed a grain-based diet compared to those fed a forage-based diet [27], which may indicate their ability to scavenge available soluble carbohydrates in the rumen when more numerous bacterial populations are reduced. This can potentially impact food safety since Zeineldin et al. [28] found that along with other pathogenic bacteria, this bacterial genus increased in the feces of feedlot cattle displaying hemorrhagic diarrhea. Unfortunately, the present study's inability to detect many known foodborne pathogenic bacteria in the rumen prevents a similar correlation from being found. Still, these bacteria's association with disease and pathogen incidence could indicate a connection between dysbiosis in the ruminal microbial population and opportunistic pathogen colonization.

Ruminal methanogens, such as Methanosphaera, are generally thought to waste dietary energy in the rumen that would normally be utilized by the animal and can represent a loss of up to $12 \%$ of carbon and energy in the diet [29]. Methanosphaera produces methane in the rumen via hydrogen-dependent reduction of methanol [30]. Furthermore, Methanosphaera has been found in greater abundance in inefficient steers compared to efficient steers based on RFI [31]. Additionally, it was found to be increased in humans with inflammatory bowel disease compared to healthy humans [32]. Thus, the ruminal increase in the relative abundance of Methanosphaera after pre-slaughter fasting may negatively affect the host by redirecting nutrients away from propionate production and ultimately contributing to host inefficiency and a decrease in host health.

Campylobacter and Non-typhoidal Salmonella are the main causes of foodborne illnesses in the United States, England and Wales, and Australia [33]. Campylobacter is responsible for $9 \%$ of the foodborne illnesses in the United States and accounts for $15 \%$ of total foodbornerelated hospitalizations [34]. The total direct and indirect cost of each human case of Campylobacter is estimated to be USD 1846 [35]. Ruminal Campylobacter populations tended to be higher following fasting, indicating that this opportunistic foodborne pathogenic bacterium can increase in abundance during pre-slaughter fasting, which increases its chance of entering the food chain.

The relative abundance of the genus Treponema had a tendency to increase after preslaughter fasting. Although Tajima et al. [1] found ruminal concentrations of Treponema bryantii decreased when diet was changed from forage to grain, previous results showed that after a $16 \mathrm{~h}$ incubation period, there was an increase in ruminal Spirochaetes driven largely by an increase in Treponema [36]. These results suggest that although diet can impact the abundance of Treponema, this bacterium can increase in abundance if the pressure of the diet on the microbial population is removed completely. Treponema was positively correlated to butyrate concentrations before and after fasting, further indicating Treponema's ability to scavenge available nutrients present at low concentrations. While Treponema has been shown to interact with cellulolytic bacteria in the rumen [37], this genus also contains many pathogenic species. Numerous studies have found multiple species of Treponema associated with digital dermatitis in dairy cattle and sheep [38-40]. Additionally, Sullivan et al. [41] found the GIT was a reservoir for pathogenic Treponema species in both 
beef cattle and sheep. Therefore, Treponema could be an opportunistic pathogen that benefits from removal of the selective pressure of the diet.

Acetate, propionate, isobutyrate, isovalerate, valerate, and total VFA concentrations were not changed by pre-slaughter fasting. However, butyrate concentration had a tendency to decrease after pre-slaughter fasting. These findings suggest that although there was not a regular flow of nutrients, the ruminal bacteria scavenged nutrients from an increasingly nutrient-sparse environment and continued to produce energy sources (VFA) for the host animal. Although the decrease in total VFA concentration due to fasting in our study was small, these findings are similar to other studies, which found ruminal VFA concentrations decreased with prolonged fasting [42,43]. In the present study, butyrate concentrations tended to decrease in the rumen due to fasting. Butyrate is known as the "healthy gut" VFA because GIT epithelial cells utilize it as an energy source to keep the gut functioning properly [44]. Decreased butyrate concentrations could indicate that the minor bacterial families that increased in abundance after fasting do not produce as much butyrate as those found in higher abundance prior to pre-slaughter fasting.

With the current lack of data available on the effects of pre-slaughter fasting on ruminal microorganisms, this preliminary study lays the groundwork into how the relative abundances of microbes in the rumen change as a result of pre-slaughter fasting. Although the data provide valuable insight into how ruminal dysbiosis can introduce harmful bacteria into the ruminal microbiota, this preliminary study still has some limitations. One of these limitations is due to the technology available for the small-scale study, limiting results to relative bacterial abundances. Future studies need to be conducted using qPCR in order to determine the exact quantity of each bacterial species highlighted in this study to determine their risk to human and animal health. Since the major foodborne pathogens (e.g., STEC and Salmonella) are typically most associated with the hindgut of cattle, further studies need to be conducted to see how pre-slaughter fasting affects other portions of the ruminant gastrointestinal microbiota to determine if the increase in harmful bacteria in the rumen would also occur in the hindgut. Although the sample size was relatively small, our findings highlight the importance of selection pressure provided by the diet and the negative impacts of the removal of the selective pressure on the host animal's microbial ecology and, consequently, on the meat industry as a whole. Additionally, elucidating which microbial species contribute to the changes in relative microbial abundances after fasting can shed light on concerns about the possibility of fasting, contributing to an increase in harmful ruminal pathogens.

\section{Conclusions}

Collectively, our results showed that as steers were fasted prior to slaughter, their ruminal microbial consortium underwent major fluctuations. The total number of bacterial species increased, along with an increase in evenness and overall diversity of the ruminal microbiota. This shift was partially explained by the two most abundant bacterial families (Prevotellaceae and Ruminococcaceae), which decreased after fasting and created niches for other opportunistic and potentially harmful bacteria. Furthermore, the minor families prior to fasting increased in abundance after fasting. Additionally, many bacterial genera found to have deleterious effects in cattle, humans, or the environment increased after fasting, including Blautia, Methanospeara, Campylobacter, and Treponema. These results suggest that when the selection pressure applied to the ruminal microbes by the diet is removed, the microbial consortium experienced dysbiosis providing pathogens an opportunity to thrive in the rumen and, ultimately, harm the environment or enter the human food chain.

Supplementary Materials: The following are available online at https:/ / www.mdpi.com/article/ 10.3390/microorganisms9122625/s1, Figure S1: Taxonomic profiles at the phylum (a) and family (b) levels of the relative bacterial abundance of the rumen at lairage and slaughter of Angus steers $(n=15)$. 
Author Contributions: C.B.W. wrote the manuscript with the help of all the authors. C.B.W., J.M.L., D.S.S. and T.R.K. collected data and performed data analysis. J.M.L., D.S.S., T.R.K., M.J.R., T.D.P. and T.R.C. revised the manuscript. All authors have read and agreed to the published version of the manuscript.

Funding: C.B.W. and D.S.S. assistantships were supported by the National Science Foundation: Grant No. DGE-1545433.

Data Availability Statement: The data have been made publicly available, and readers can find it at: https: / / www.mg-rast.org (accessed on 1 November 2021) using the accession number: mgm4909317.3.

Acknowledgments: The authors would like to express their appreciation to Brasstown Beef LLC, the Georgia Commodity Commission for Beef, and the Angus Foundation for financial support.

Conflicts of Interest: The authors declare no conflict of interest.

\section{References}

1. Tajima, K.; Aminov, R.I.; Nagamine, T.; Matsui, H.; Nakamura, M.; Benno, Y. Diet-Dependent Shifts in the Bacterial Population of the Rumen Revealed with Real-Time PCR. Appl. Environ. Microbiol. 2001, 67, 2766-2774. [CrossRef] [PubMed]

2. De Menezes, A.B.; Lewis, E.; O’Donovan, M.; O’Neill, B.F.; Clipson, N.; Doyle, E.M. Microbiome analysis of dairy cows fed pasture or total mixed ration diets. FEMS Microbiol. Ecol. 2011, 78, 256-265. [CrossRef]

3. Carberry, C.A.; Kenny, D.; Han, S.; McCabe, M.S.; Waters, S.M. Effect of Phenotypic Residual Feed Intake and Dietary Forage Content on the Rumen Microbial Community of Beef Cattle. Appl. Environ. Microbiol. 2012, 78, 4949-4958. [CrossRef] [PubMed]

4. Mizrahi, I. Rumen Symbioses, the Prokaryotes: Prokaryotic Biology and Symbiotic Associations; Springer: Berlin/Heidelberg, Germany, 2013; pp. 533-544.

5. Flint, H.J.; Bayer, E.A. Plant Cell Wall Breakdown by Anaerobic Microorganisms from the Mammalian Digestive Tract. Ann. N. Y. Acad. Sci. 2008, 1125, 280-288. [CrossRef]

6. Hobson, P.N.; Stewart, C.S. The Rumen Microbial Ecosystem; Springer Science \& Business Media: New York, NY, USA, 2012.

7. Krause, D.O.; Denman, S.; Mackie, R.I.; Morrison, M.; Rae, A.L.; Attwood, G.; McSweeney, C. Opportunities to improve fiber degradation in the rumen: Microbiology, ecology, and genomics. FEMS Microbiol. Rev. 2003, 27, 663-693. [CrossRef]

8. Wolin, M.J. Volatile Fatty Acids and the Inhibition of Escherichia coli Growth by Rumen Fluid. Appl. Microbiol. 1969, 17, 83-87. [CrossRef]

9. Brownlie, L.E.; Grau, F.H. Effect of Food Intake on Growth and Survival of Salmonellas and Escherichia coli in the Bovine Rumen. J. Gen. Microbiol. 1967, 46, 125-134. [CrossRef]

10. Pointon, A.; Kiermeier, A.; Fegan, N. Review of the impact of pre-slaughter feed curfews of cattle, sheep and goats on food safety and carcase hygiene in Australia. Food Control. 2012, 26, 313-321. [CrossRef]

11. Rasmussen, M.A.; Cray, W.C.; Casey, T.A.; Whipp, S.C. Rumen contents as a reservoir of enterohemorrhagic Escherichia coli. FEMS Microbiol. Lett. 1993, 114, 79-84. [CrossRef]

12. Callaway, T.; Elder, R.; Keen, J.; Anderson, R.; Nisbet, D. Forage Feeding to Reduce Preharvest Escherichia coli Populations in Cattle, a Review. J. Dairy Sci. 2003, 86, 852-860. [CrossRef]

13. Nastasijevic, I. STEC O157 in the beef chain-Risk assessment and management. CAB Rev. Perspect. Agric. Veter-Sci. Nutr. Nat. Resour. 2011, 6, 61-80. [CrossRef]

14. Small, A.; Reid, C.-A.; Avery, S.M.; Karabasil, N.; Crowley, C.; Buncic, S. Potential for the Spread of Escherichia coli O157, Salmonella, and Campylobacter in the Lairage Environment at Abattoirs. J. Food Prot. 2002, 65, 931-936. [CrossRef]

15. Arthur, J.P.; Herd, R. Residual feed intake in beef cattle. Rev. Bras. Zootec. 2008, 37, 269-279. [CrossRef]

16. Herd, R.M.; Archer, J.A.; Arthur, P.F. Reducing the cost of beef production through genetic improvement in residual feed intake: Opportunity and challenges to application. J. Anim. Sci. 2003, 81 (Suppl. S1), E9-E17. [CrossRef]

17. Nkrumah, J.D.; Okine, E.K.; Mathison, G.W.; Schmid, K.; Li, C.; Basarab, J.A.; Price, M.A.; Wang, Z.; Moore, S.S. Relationships of feedlot feed efficiency, performance, and feeding behavior with metabolic rate, methane production, and energy partitioning in beef cattle1. J. Anim. Sci. 2006, 84, 145-153. [CrossRef]

18. Lourenco, J.; Callaway, T.; Kieran, T.; Glenn, T.; McCann, J.C.; Stewart, R.L.J. Analysis of the Rumen Microbiota of Beef Calves Supplemented During the Suckling Phase. Front. Microbiol. 2019, 10, 1131. [CrossRef]

19. Rothrock, M.J.; Hiett, K.L.; Gamble, J.; Caudill, A.C.; Cicconi-Hogan, K.M.; Caporaso, J.G. A Hybrid DNA Extraction Method for the Qualitative and Quantitative Assessment of Bacterial Communities from Poultry Production Samples. J. Vis. Exp. 2014, 94, e52161. [CrossRef] [PubMed]

20. Klindworth, A.; Pruesse, E.; Schweer, T.; Peplies, J.; Quast, C.; Horn, M.; Glöckner, F.O. Evaluation of general 16S ribosomal RNA gene PCR primers for classical and next-generation sequencing-based diversity studies. Nucleic Acids Res. 2013, 41, e1. [CrossRef]

21. Caporaso, J.G.; Kuczynski, J.; Stombaugh, J.; Bittinger, K.; Bushman, F.D.; Costello, E.K.; Fierer, N.; Peña, A.G.; Goodrich, J.K.; Gordon, J.I.; et al. QIIME allows analysis of high-throughput community sequencing data. Nat. Methods 2010, 7, 335-336. [CrossRef] 
22. Caporaso, J.G.; Bittinger, K.; Bushman, F.D.; DeSantis, T.Z.; Andersen, G.L.; Knight, R. PyNAST: A flexible tool for aligning sequences to a template alignment. Bioinformatics 2009, 26, 266-267. [CrossRef] [PubMed]

23. Lourenco, J.M.; Kieran, T.; Seidel, D.S.; Glenn, T.C.; Da Silveira, M.F.; Callaway, T.R.; Stewart, R.L., Jr. Comparison of the ruminal and fecal microbiotas in beef calves supplemented or not with concentrate. PLoS ONE 2020, 15, e0231533. [CrossRef]

24. Petri, R.M.; Schwaiger, T.; Penner, G.B.; Beauchemin, K.A.; Forster, R.J.; McKinnon, J.J.; McAllister, T.A. Characterization of the core rumen microbiome in cattle during transition from forage to concentrate as well as during and after an acidotic challenge. PLoS ONE 2013, 8, e83424. [CrossRef]

25. Thoetkiattikul, H.; Mhuantong, W.; Laothanachareon, T.; Tangphatsornruang, S.; Pattarajinda, V.; Eurwilaichitr, L.; Champreda, V. Comparative Analysis of Microbial Profiles in Cow Rumen Fed with Different Dietary Fiber by Tagged 16S rRNA Gene Pyrosequencing. Curr. Microbiol. 2013, 67, 130-137. [CrossRef]

26. Dias, J.; Marcondes, M.; de Souza, S.M.; Silva, B.C.D.M.E.; Noronha, M.; Resende, R.T.; Machado, F.S.; Mantovani, H.C.; DillMcFarland, K.A.; Suen, G. Bacterial Community Dynamics across the Gastrointestinal Tracts of Dairy Calves during Preweaning Development. Appl. Environ. Microbiol. 2018, 84, e02675-17. [CrossRef]

27. Kim, M.; Kim, J.; Kuehn, L.A.; Bono, J.L.; Berry, E.D.; Kalchayanand, N.; Freetly, H.C.; Benson, A.K.; Wells, J.E. Investigation of bacterial diversity in the feces of cattle fed different diets. J. Anim. Sci. 2014, 92, 683-694. [CrossRef]

28. Zeineldin, M.; Aldridge, B.; Lowe, J. Dysbiosis of the fecal microbiota in feedlot cattle with hemorrhagic diarrhea. Microb. Pathog. 2018, 115, 123-130. [CrossRef] [PubMed]

29. Johnson, K.A.; Johnson, D.E. Methane emissions from cattle. J. Anim. Sci. 1995, 73, 2483-2492. [CrossRef] [PubMed]

30. Hoedt, E.; Parks, D.H.; Volmer, J.G.; Rosewarne, C.; Denman, S.; McSweeney, C.; Muir, J.G.; Gibson, P.R.; Cuív, P.Ó.; Hugenholtz, P.; et al. Culture- and metagenomics-enabled analyses of the Methanosphaera genus reveals their monophyletic origin and differentiation according to genome size. ISME J. 2018, 12, 2942-2953. [CrossRef]

31. Zhou, M.; Hernandez-Sanabria, E.; Guan, L.L. Assessment of the Microbial Ecology of Ruminal Methanogens in Cattle with Different Feed Efficiencies. Appl. Environ. Microbiol. 2009, 75, 6524-6533. [CrossRef] [PubMed]

32. Lecours, P.B.; Marsolais, D.; Cormier, Y.; Berberi, M.; Haché, C.; Bourdages, R.; Duchaine, C. Increased Prevalence of Methanosphaera stadtmanae in Inflammatory Bowel Diseases. PLoS ONE 2014, 9, e87734. [CrossRef]

33. Park, S.F. The physiology of Campylobacter species and its relevance to their role as foodborne pathogens. Int. J. Food Microbiol. 2002, 74, 177-188. [CrossRef]

34. Scallan, E.; Hoekstra, R.M.; Angulo, F.J.; Tauxe, R.V.; Widdowson, M.-A.; Roy, S.L.; Jones, J.L.; Griffin, P.M. Foodborne Illness Acquired in the United States-Major Pathogens. Emerg. Infect. Dis. 2011, 17, 7-15. [CrossRef] [PubMed]

35. Scharff, R.L. Economic Burden from Health Losses Due to Foodborne Illness in the United States. J. Food Prot. 2012, 75, 123-131. [CrossRef] [PubMed]

36. Epiao, H.; Elachman, M.; Emalfatti, S.; Sczyrba, A.; Eknierim, B.; Eauer, M.; Tringe, S.; Mackie, R.I.; Yeoman, C.J.; Ehess, M. Temporal dynamics of fibrolytic and methanogenic rumen microorganisms during in situ incubation of switchgrass determined by $16 \mathrm{~S}$ rRNA gene profiling. Front. Microbiol. 2014, 5, 307. [CrossRef]

37. Kudo, H.; Cheng, K.-J.; Costerton, J.W. Interactions between Treponema bryantii and cellulolytic bacteria in the in vitro degradation of straw cellulose. Can. J. Microbiol. 1987, 33, 244-248. [CrossRef] [PubMed]

38. Döpfer, D.; Anklam, K.; Mikheil, D.; Ladell, P. Growth curves and morphology of three Treponema subtypes isolated from digital dermatitis in cattle. Veter-J. 2012, 193, 685-693. [CrossRef]

39. Sullivan, L.E.; Clegg, S.; Angell, J.W.; Newbrook, K.; Blowey, R.W.; Carter, S.D.; Bell, J.; Duncan, J.S.; Grove-White, D.H.; Murray, R.D.; et al. High-Level Association of Bovine Digital Dermatitis Treponema spp. with Contagious Ovine Digital Dermatitis Lesions and Presence of Fusobacterium necrophorum and Dichelobacter nodosus. J. Clin. Microbiol. 2015, 53, 1628-1638. [CrossRef]

40. Trott, D.J.; Moeller, M.R.; Zuerner, R.L.; Goff, J.P.; Waters, W.R.; Alt, D.P.; Walker, R.L.; Wannemuehler, M.J. Characterization of Treponema phagedenis -Like Spirochetes Isolated from Papillomatous Digital Dermatitis Lesions in Dairy Cattle. J. Clin. Microbiol. 2003, 41, 2522-2529. [CrossRef]

41. Sullivan, L.E.; Carter, S.D.; Duncan, J.S.; Grove-White, D.H.; Angell, J.W.; Evans, N.J. The Gastrointestinal Tract as a Potential Infection Reservoir of Digital Dermatitis-Associated Treponemes in Beef Cattle and Sheep. Appl. Environ. Microbiol. 2015, 81, 7460-7469. [CrossRef] [PubMed]

42. Bryant, A.M. Variations in the $\mathrm{pH}$ and volatile fatty acid concentration within the bovine reticulo-rumen. New Zealand J. Agric. Res. 1964, 7, 694-706. [CrossRef]

43. Stewart, W.E.; Stewart, D.G.; Schultz, L.H. Rates of Volatile Fatty Acid Production in the Bovine Rumen1. J. Anim. Sci. 1958, 17, 723-736. [CrossRef]

44. Guan, L.L.; Nkrumah, J.D.; Basarab, J.A.; Moore, S. Linkage of microbial ecology to phenotype: Correlation of rumen microbial ecology to cattle's feed efficiency. FEMS Microbiol. Lett. 2008, 288, 85-91. [CrossRef] [PubMed] 